\title{
Evaluating the effectiveness of local materials for the wild oyster (Crassostrea tulipa Lamarck, 1819) spat collection in four coastal waterbodies in Ghana
}

Ernest Obeng Chuku ( $\nabla$ eobengchuku@ucc.edu.gh )

Department of Fisheries and Aquatic Sciences, School of Biological Sciences, University of Cape Coast,

PMB Cape Coast, Ghana

\section{Kobina Yankson}

Department of Fisheries and Aquatic Sciences, School of Biological Sciences, University of Cape Coast, PMB Cape Coast, Ghana

\section{Edward Adzesiwor Obodai}

Department of Fisheries and Aquatic Sciences, School of Biological Sciences, University of Cape Coast, PMB Cape Coast, Ghana

\section{Emmanuel Acheampong}

Department of Fisheries and Aquatic Sciences, School of Biological Sciences, University of Cape Coast,

PMB Cape Coast, Ghana

\section{Eunice Efua Boahemaa-Kobil}

Department of Animal and Aquacultural Sciences (IHA), Norwegian University of Life Sciences, Norway

\section{Research Article}

Keywords: Crassostrea tulipa, Spatfall, Spat collectors, Collector effectiveness, Mangrove oyster

Posted Date: September 29th, 2020

DOI: https://doi.org/10.21203/rs.3.rs-84196/v1

License: (c) (i) This work is licensed under a Creative Commons Attribution 4.0 International License. Read Full License

Version of Record: A version of this preprint was published at Aquaculture Reports on September 29th, 2020. See the published version at https://doi.org/10.1016/j.aqrep.2020.100493. 


\section{Abstract}

The West African mangrove oyster, Crassostrea tulipa (Lamarck, 1819), has the potential to improve global shellfish food production and is being considered for commercial farming in many countries in West Africa. The current background information to support this venture is, however, inadequate especially with respect to identification of suitable materials for optimal collection of spat for large-scale production. We assessed the effectiveness of five locally available materials (coconut shell, oyster shell, nylon mesh, PVC, and ceramic tile) for harvesting C. tulipa spat from the Densu Delta, Narkwa Lagoon, Benya Lagoon and Whin Estuary, along the coast of Ghana from November 2017 to October 2018. Ceramic tile had the highest mean monthly spat settlement in the Narkwa Lagoon (3451 $\pm 206 \mathrm{spat} \mathrm{m}^{-2}$ ),

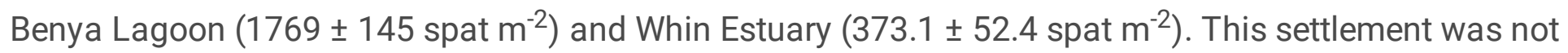
significantly different from settlement on PVC slats $(P>0.05)$. Coconut shell consistently had the least $C$. tulipa spatfall in all four coastal water bodies $(P<0.05)$. The under-horizontal surfaces of collectors, [mean (S.E.); $2523.7 \pm 66.9$ spat $\mathrm{m}^{-2}$ ] had significantly more $C$. tulipa spatfall than upper-horizontal

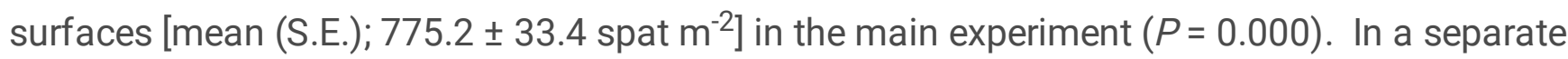
experiment, a change of orientation from "Face down" $/ 0^{\circ}$ to "Face up" $/ 180^{\circ}$ did not change the observed profuse under-horizontal settlement of $C$. tulipa spat on the collectors, suggesting that under-horizontal surfaces were more attractive to $C$. tulipa spat. Larger-sized $C$. tulipa spat on under-horizontal surfaces, mean (S.E.) $9.88 \pm 0.5 \mathrm{~mm}$, compared to upper-horizontal surfaces, mean (S.E.) $5.99 \pm 0.5 \mathrm{~mm}$, of the collectors suggest earlier settlement on the undersides. Ceramic tiles and PVC slats were the most effective materials for $C$. tulipa spat collection, hence, their use recommended for large-scale $C$. tulipa farming.

\section{Introduction}

The mangrove oyster, Crassostrea tulipa, serves as a major source of animal protein for many coastal communities in West African (Adite et al., 2013; Asare et al., 2019). The shells are also used in the indigenous production of paints, traditional medicine and concrete for building (Yankson, 2004). The species is often found either on sandy-mud sediments or attached to mangrove roots and other hard objects in lagoons and estuaries along the coast of West Africa. It is naturally well adapted to the rigorous environmental conditions, surviving wide temperature ranges $20-30^{\circ} \mathrm{C}$ (Ajana, 1980), $24-31.5^{\circ} \mathrm{C}$ and $27-36^{\circ} \mathrm{C}$ (Obodai et al., 1991). Due to easy accessibility of its habitats, the fishery of the oyster is dominated by women (Theisen, 2010; FAO, 2014) who are estimated to earn as much as US $\$ 150.00$ per month mainly through the collection, processing and sale of the oyster (Cormier-Salem et al., 2010). In order to sustain and possibly enhance the earnings and nutritional benefits derived from $C$. tulipa, many coastal communities in West Africa are considering farming the oyster on a large scale (Ishengoma et al., 2011). Further, threats of mass mortalities due to diseases, in the tilapia aquaculture sector which is about $95 \%$ of total aquaculture production in some West African counties e.g. from the Volta Lake in Ghana (FAO, 2018), raises deep concerns for the diversification of cultured species and geographical coverage in the development of aquaculture. Hence, the efforts to farm the native oysters. 
The culturabiliy of $C$. tulipa has been established within the last three decades (Kamara, 1982; Yankson, 1990). Recent studies have also farmed the oyster to marketable size within a reasonable period of time using cultches prepared from coconut shells (Asare et al., 2019). However, efforts towards large-scale culture of $C$. tulipa are impeded by myriad factors including inadequate scientific data on the local hydrodynamic conditions that promote the recruitment, larval export to new favourable areas, and suitable microhabitats for its growth. The biological, physiological and mechanical considerations in seed production and the methods for doing so are also not fully understood. In addition, research on appropriate hatchery techniques that can be used to mass-produce the spat of $C$. tulipa for onward transfer to suitable locations in costal water bodies is limited. Yankson (1990) successfully produced gametes of the species from artificial fertilization through to settlement. This development was stalled by the unavailability of facilities for culturing marine microalgae to feed larvae and spat in the laboratory, which is expensive and not easily reproducible in poor areas (Dégremont et al., 2007; Mann, 1983; Tanyaros and Chuseingjaw, 2016).

Due to the foregoing limitations, and as done for other species of oysters in different parts of the world (Gosling, 2015; Quayle and Newkirk, 1989), spat for farming C. tulipa could be harvested from the wild using artificially introduced substrates or cultches. Elsewhere, these artificial collectors include concrete slabs (Pillay and Kutty, 2005), plastic mesh nettings in different forms and shapes (Friedman et al., 1998; Southgate and Lucas, 2008; Taylor et al., 1998a; Urban, 2000), plastic polyethylene sheet (Friedman et al., 1998; Nayar et al., 1980), polyvinyl chloride (PVC) materials (Helm and Bourne, 2004; Taylor et al., 1998a), empty oyster shells (Pillay and Kutty, 2005), tiles (Giese and Pearse, 1979; Miller and Hall, 1995) and empty coconut shells (Quayle and Newkirk, 1989). These records suggest that the spat of the oyster settle on a wide range of materials.

For the profitability of farming operations, the use of cheap, durable and locally available cultches are recommended (Vakily, 1989). It is also prudent to measure cost against yield to maximise profitability in any aquaculture business (Ahmed, 2007). Therefore, other strategic considerations on the suitability and effectiveness of collectors and their positional orientations would be worthwhile in the farming of $C$. tulipa. Previous studies suggest best yield of spat of other oyster species on collectors placed horizontally in water column (see for example Hopkins, 1937 [Olympia oyster, Ostrea lurida]; Schaefer, 1937 [Japanese oyster, Ostrea gigas]; Cole and Knight-Jones, 1939 [European flat oyster, Ostrea edulisis]), with no record for $C$. tulipa. That aside, accounts of spat settlement and yield on the different surfaces of horizontally placed collectors are not consistent (Friedman et al., 1998; Soria et al., 2015; Taylor et al., 1998a), and needs to be investigated for different species of varying ecosystems.

As part of a broader scope of research on $C$. tulipa towards the large-scale farming of the species along the coast of West Africa, this study set out to assess the effectiveness of five locally available materials for the collection of $C$. tulipa spat for culture. The materials were coconut shells, empty shells of $C$. tulipa, nylon net, Polyvinylchloride (PVC) material and ceramic tiles. Their relative effectiveness and effects of their surface contour relative to horizontal orientation in the water column were evaluated in four coastal 
water bodies along the coast of Ghana. We have discussed our results in the context of previous findings on other species of oysters from other ecosystems.

\section{Materials And Methods}

\subsection{Preparation of collectors and construction of cultches}

The spat collector materials investigated in this study were coconut shell, nylon net (mesh size $=2 \mathrm{~mm}$ ), oyster shell, PVC and ceramic tiles (Figure 1). Coconut shells, with husk removed, were collected from fields around the study area, cleaned, washed in sea water and dried before using for the study. Fine mesh nylon nettings were cut out into sizes of $10 \times 10 \mathrm{~cm}^{2}$. Oyster shells were obtained and treated the same as the coconut shells before use. PVC pipes (diameter $\approx 10 \mathrm{~cm}$ ) were cut into smaller curved slats of height and surface area $10 \mathrm{~cm}$ and $106 \mathrm{~cm}^{2}$, respectively. Fifty-by-fifty $\mathrm{cm}^{2}$ ceramic tiles were also diced into smaller sizes of $10 \times 10 \mathrm{~cm}^{2}$.

Each collector type was strung together in threes on polypropylene ropes, using the approach described by (Chuku and Osei, 2017) in order to minimise wastage of cultch construction materials. The three collectors were fastened on each rope through holes (diameter $\approx 4 \mathrm{~mm}$ ) drilled at the centre and kept equidistant from each other on the rope by knots to form a cultch. Collectors in a cultch were held horizontally on the ropes in order to ensure maximum spat harvest as observed in previous studies (Hopkins, 1937; Schaefer, 1937; Cole and Knight-Jones, 1939). The lengths of the ropes were varied, depending on average high water depth at each station within the water bodies selected for this study. The vertical location of collectors along the length of each rope was designated "top", "middle" and "bottom" at each experimental station in the selected water bodies.

\subsection{Determination of surface area of irregular collectors}

To standardize the estimate of total spatfall in this experiment, the surface area of the collectors was used $(S f=\mathrm{Ns} / \mathrm{Ac}$; Where $S f=$ spatfall, Ns = number of spat on collector surface, and Ac = surface area of collector). For coconut and oyster shells, their surface areas were determined by first tracing the outline of their shapes on a square-grid paper (grid size $=2 \mathrm{~cm}$ subdivided into $0.2 \mathrm{~cm}$ minor grids) and the total grid area that fell within each outline taken as the area of one surface. Collectors made from nylon mesh, PVC, and ceramic tiles were cut into definite sizes (see section 2.1). Hence, their surface areas were determined by a multiplication of the length by breadth. The surface area values were then multiplied by two to obtain the total surface areas of the collectors.

\subsection{Study sites, experimental design and data collection}

Based on field surveys and previous reports on thriving populations of $C$. tulipa in Ghana (Asare et al., 2019; Janha et al., 2017; Obodai and Yankson, 2002; Yankson, 1990), four coastal waters bodies were selected for this study (Figure 2). These were the Densu Delta $\left(0^{\circ} 16^{\prime} 43^{\prime \prime} \mathrm{W}, 5^{\circ} 34^{\prime} 07^{\prime \prime} \mathrm{N}\right.$ and $0^{\circ} 20^{\prime} 02^{\prime \prime} \mathrm{W}$,

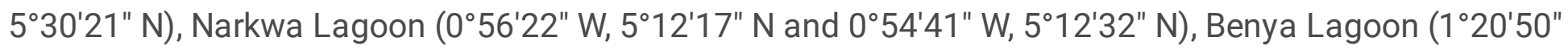


W, 5 $04^{\prime} 59^{\prime \prime} \mathrm{N}$ and $\left.1^{\circ} 21^{\prime} 26^{\prime \prime} \mathrm{W}, 5^{\circ} 05^{\prime} 18^{\prime \prime} \mathrm{N}\right)$ and Whin Estuary ( $1^{\circ} 46^{\prime} 47^{\prime \prime} \mathrm{W}, 4^{\circ} 52^{\prime} 52^{\prime \prime} \mathrm{N}$ and $1^{\circ} 46^{\prime} 04^{\prime \prime} \mathrm{W}$, $\left.4^{\circ} 52^{\prime} 30^{\prime \prime} \mathrm{N}\right)$. Three experimental stations (ST) were established in each water body to cover the head, middle and mouth regions, except for Densu Delta where ST3-DD was eliminated due persistent destruction of racks by local fishers (Figure 2). At each experimental station, three cultches each of the five different collector materials were deployed on a fixed bamboo rack; each cultch was made of three units of same collector material. A total of 45 collectors were, therefore, deployed per station and 540 for all the water bodies combined. Sampling was done monthly for one year from November 2017 to October 2018 by harvesting all cultches and replacing with a new set each month. Cultches were examined in the laboratory for settled spat on the collectors. The total number of spat on each collector was counted under a laboratory lamp; which provided a higher localised luminescence relative to laboratory ambience. A hand lens was used in instances of very small spat of shell height $<1 \mathrm{~mm}$. Mean spatfall per $\mathrm{m}^{2}$ was then calculated using the equation:

$$
\bar{X} S f\left(\mathrm{~m}^{-2}\right)=\left[n^{-1} \cdot \sum_{i=1}^{n}\left(S f_{i}\right)\left(\mathrm{cm}^{-2}\right)\right] \times 10000
$$

Where $\overline{\bar{X}} S f=$ mean spatfall, $S f_{i}=$ spatfall on individual collectors, $i=1,2,3 \ldots n^{\text {th }}$ replicate collector, and $\mathrm{n}=$ number of replicate collectors/surfaces.

\subsection{Crassostrea tulipa spat settlement on upper-and under-horizontal surfaces of collectors}

The number of settled $C$. tulipa spat was counted separately for the upper- and under-horizontal surfaces of each individual cultch deployed. Another spatfall experiment was set up in March 2018, in the Densu Delta and Narkwa Lagoon, alongside the main experiment, to verify the general observation of relatively more spat setting on the underside of collectors than the upper side during the first three months of sampling. Since the two sides of each collector material were characteristically different either in texture, shape or contour, it was found necessary to test the influence of the surface in the horizontal position. In this confirmatory experiment for $C$. tulipa, collectors were strung in the opposite direction to the regular spatfall experiment as shown in Figure 3, on separate racks. The nylon mesh was excluded in this experiment. Spat were counted, shell heights $\left(\mathrm{SH}\right.$ ) were measured and a $0^{\circ}$ (face down) versus $180^{\circ}$ (face up) comparison of the surfaces was done statistically.

\subsection{Data analysis}

The comparative effectiveness of the different collectors within individual water bodies was done using a three-way Analysis of Variance (ANOVA). The sources of variance in this analysis were the different stations within each water body, sampling month and type of collectors used. A mixed model multi-way ANOVA was used to compare the effectiveness of the collectors between the different water bodies. Here, type of collector, water body, and sampling month were the fixed factors, sampling station was a random factor, whilst the response was spatfall on the collectors. The analysis was done using General Linear 
Model function in Minitab ${ }^{\circledR}$, version18.1. The effect of surface contour on $C$. tulipa spatfall on the upperand under-horizontal surfaces of the collectors within water body was determined using a three-way ANOVA (collector surface $\times$ collector material $\times$ collector orientation). The critical $p$-value for all the ANOVA was taken to be 0.05 . Tukey's HSD $(a=0.05)$ was used as the post-hoc test to determine which pairs of means were significantly different. Homogeneity of the variance in the data was verified using Levene's Test and data transformed to $\log _{10}(x+1)$, where necessary, prior to ANOVA. Further, significant differences between the most effective collector material (highest mean spatfall) for harvesting $C$. tulipa spat and the other collectors, were identified using the Hsu's Multiple Comparison with Best (MCB) method (Hsu, 1992) using a $5 \%$ family error rate. The difference of means was used to rank collectors relative to the best. Each spatfall value was obtained over a duration of one month.

\section{Results}

\subsection{C. tulipa spatfall on artificial collectors}

Figure 4 shows the effectiveness of different collectors, evaluated using the number of spat collected per unit area. No spat was observed on cultches made from nylon mesh net during the first three months of this study hence its use was discontinued. Of the remaining cultches, significant differences in the densities of $C$. tulipa spat were observed in all the water bodies combined (Mixed model multi-way ANOVA at $\mathrm{p}<0.05$; Table 1). On average, spatfall was highest on ceramic tile $\left(2007.4 \pm 85.5 \mathrm{spat} \mathrm{m}^{-2}\right)$ followed by PVC slat (spatfall $=1846.7 \pm 88.2 \mathrm{~m}^{-2}$ ), oyster shell (spatfall $=1697.2 \pm 72.6 \mathrm{~m}^{-2}$ ) and coconut shell (spatfall $=1046.5 \pm 55.6 \mathrm{~m}^{-2}$ ), in that order. This differential order was however not maintained in all water bodies throughout the study period as changes occurred in some months (see interaction between collector materials and the sampling month, $P=0.000$, or interaction between collector materials, water body and sampling month considered in the statistical analysis, $P=0.168$; Table 1). Hsu's MCB test following Tukey's HSD, showed spatfall on ceramic tile (highest mean spatfall) was significantly greater than those observed on both coconut and oyster shells $(P<0.01)$; it was not significantly different from the observation on PVC $(P=0.156)$. The performance of each collector, however, increased with increasing availability of spat from one water body to the other (Figure 4). The significant differences in effectiveness of spat collectors at harvesting $C$. tulipa spat in this study could not be related to third and fourth term interactions with water body, station, depth and/or month except for $\mathrm{CM} \times \mathrm{WB} \times \mathrm{M}$ (Table 1).

Table 1 - Results of multi-way ANOVA (mixed model) for the effects of type of collector material (fixed factor) on $C$. tulipa spatfall in three columns of water depth (fixed factor) at each of eleven stations (random factor - nested in water body) monthly (fixed factor) throughout the sampling year. Only interactions with type of collector material are shown. 


\begin{tabular}{llllll}
\hline Source & DF & Adj SS & Adj MS & F-Value & P-Value \\
\hline Collector material (CM) & 3 & 221.3 & 73.75 & 78.48 & 0.000 \\
\hline Water body (WB) & 3 & 3459.8 & 1153.28 & 1227.28 & 0.000 \\
\hline Station (Water body) (ST) & 7 & 295.8 & 42.26 & 44.97 & 0.000 \\
\hline Depth (D) & 2 & 1479.9 & 739.96 & 787.44 & 0.000 \\
\hline Month (M) & 11 & 5067.2 & 460.65 & 490.21 & 0.000 \\
\hline $\mathrm{CM} \times \mathrm{WB}$ & 9 & 32.2 & 3.58 & 3.81 & 0.000 \\
\hline $\mathrm{CM} \times \mathrm{ST}$ & 21 & 35.3 & 1.68 & 1.79 & 0.015 \\
\hline $\mathrm{CM} \times \mathrm{D}$ & 6 & 46.6 & 7.77 & 8.27 & 0.000 \\
\hline $\mathrm{CM} \times \mathrm{M}$ & 33 & 75.4 & 2.29 & 2.43 & 0.000 \\
\hline $\mathrm{CM} \times \mathrm{WB} \times \mathrm{D}$ & 18 & 26.9 & 1.49 & 1.59 & 0.053 \\
\hline $\mathrm{CM} \times \mathrm{WB} \times \mathrm{M}$ & 99 & 153.9 & 1.55 & 1.65 & 0.000 \\
\hline $\mathrm{CM} \times \mathrm{D} \times \mathrm{M}$ & 66 & 50.6 & 0.77 & 0.82 & 0.857 \\
\hline $\mathrm{CM} \times \mathrm{ST} \times \mathrm{D}$ & 42 & 27.1 & 0.65 & 0.69 & 0.938 \\
\hline $\mathrm{CM} \times \mathrm{ST} \times \mathrm{M}$ & 231 & 177.2 & 0.77 & 0.82 & 0.980 \\
\hline $\mathrm{CM} \times \mathrm{WB} \times \mathrm{D} \times \mathrm{M}$ & 198 & 137.1 & 0.69 & 0.74 & 0.998 \\
\hline $\mathrm{CM} \times \mathrm{ST} \times \mathrm{D} \times \mathrm{M}$ & 462 & 221.2 & 0.48 & 0.51 & 1.000 \\
\hline $\mathrm{Error}$ & 7920 & 7442.5 & 0.94 & & \\
\hline $\mathrm{T}$ tat & 9503 & 24204.7 & & & \\
\hline & & & & & \\
\hline
\end{tabular}

There were also significant differences in spat settlement on collectors within each water body investigated in this study (Figure 4). In the Densu Delta system, spatfall (mean \pm S.E.) was highest on PVC $\left(2880 \pm 294 \mathrm{~m}^{-2}\right)$, followed by Ceramic tile $\left(2651 \pm 234 \mathrm{~m}^{-2}\right)$, oyster shell $\left(2344 \pm 200 \mathrm{~m}^{-2}\right)$ and coconut shells (1238 \pm 128 spat $\left.\mathrm{m}^{-2}\right)$ in decreasing order. A post hoc Tukey's Hsu MCB test showed no significant difference in spatfall on PVC slats and ceramic tiles $(P=0.438)$ as well as between the PVC and oyster shells $(P=0.105)$. In contrast, spatfall on PVC was significantly higher i.e. $\approx 233 \%$ of spatfall on coconut shell (Hsu's MCB test; $P=0.000$ ). However, spatfall on the coconut shells was $\approx 47 \%$ of that on ceramic tiles (Tukey's Hsu MCB test; $P=0.000$ ) and $\approx 53 \%$ of the average spatfall on oyster shells (Tukey's Hsu MCB test; $P=0.002$ ).

In the Narkwa Lagoon, C. tulipa spatfall (mean \pm S.E.) was $2168 \pm 157 \mathrm{~m}^{-2}, 3165 \pm 191 \mathrm{~m}^{-2}, 3112 \pm 203$ $\mathrm{m}^{-2}$, and $3451 \pm 206 \mathrm{~m}^{-2}$ for coconut shells, oyster shells, PVC slats and ceramic tiles, respectively. The difference between the ceramic tiles and oyster shells, as well as the PVC slats was not statistically significant (Hsu's MCB test; $p>0.05$ ]. However, coconut shell harvested significantly lower numbers $(\approx 63$ - $70 \%$ ) of $C$. tulipa spat on the other collectors deployed in the Narkwa Lagoon (Tukey Hsu (MCB) Test: $P$ $=0.000-0.003)$. 
In the Benya Lagoon, spatfall (mean \pm S.E.) on coconut shells, oyster shells, PVC and Ceramic tiles were $710.2 \pm 75.6 \mathrm{~m}^{-2}, 1219.8 \pm 89.4 \mathrm{~m}^{-2}, 1393 \pm 122 \mathrm{~m}^{-2}$, and $1769 \pm 145 \mathrm{~m}^{-2}$ respectively. Again, average spatfall was highest on ceramic tiles; it was $\approx 249 \%$ and $145 \%$ of the observations made on coconut and oyster shells respectively (Hsu's MCB Test; $P=0.000-0.003)$ but similar to that of PVC $(P=0.080)$. Spatfall on both the oyster shells $(P=0.007)$ and PVC $(P=0.000)$ was higher i.e. $\approx 172-196 \%$ of spatfall on coconut shell. There was no significant difference between oyster shells and PVC $(P=0.69)$.

Similarly, in the Whin Estuary, a significant difference in $C$. tulipa spatfall on the different artificial collectors was observed (Figure 4; multi-way ANOVA; $P=0.000$ ). Averaged over the entire study period, the fall on coconut shell was $134.0 \pm 23.0$ spat $\mathrm{m}^{-2}$; it was $276.3 \pm 36.2$ spat m $\mathrm{m}^{-2}, 346.3 \pm 51.6 \mathrm{spat} \mathrm{m}^{-2}$, and $373.1 \pm 52.4$ spat $\mathrm{m}^{-2}$ on oyster shells, PVC and ceramic tiles, respectively. There was no significant difference between the observations made on ceramic tiles and PVC or oyster shells (Hsu's MCB Test; $P>$ 0.05). There were, however, significant differences in $C$. tulipa spatfall on ceramic tiles and coconut shells $(P=0.000)$, as well as between the PVC slats and coconut shells $(P=0.002)$. Details of spatfall on artificial collectors at the different stations with respect to the collector with highest mean spatfall at each station compared simultaneously with the other collectors are shown in Table 2. Ceramic tile was the dominant $C$. tulipa spat collector, harvesting the most spat in 8 out of the 11 successful experimental stations.

Table 2 - Collector ranking at all eleven study stations (ST) in the Densu Delta (DD), Narkwa Lagoon (NL), Benya Lagoon (BL) and Whin Estuary (WE) using mean differences from the highest mean obtained from Hsu Simultaneous Tests for Level Mean (collector with highest mean $C$. tulipa spatfall is best; ranked $1^{\text {st }}$ ). For each station, spatfall on collectors at a lower step are significantly $(P<0.05)$ lower than the most effective $\left(1^{\text {st }}\right)$ collector. 


\begin{tabular}{|c|c|c|c|c|}
\hline \multirow[t]{2}{*}{ Sampling station } & \multicolumn{4}{|c|}{ Ranking of collector } \\
\hline & $1^{\text {st }}$ & $2^{\text {nd }}$ & $3^{\text {rd }}$ & $4^{\text {th }}$ \\
\hline \multirow[t]{2}{*}{ ST1_DD } & Ceramic tile & PVC & Oyster shell & \\
\hline & & & & Coconut shell \\
\hline \multirow[t]{2}{*}{ ST2_DD } & PVC & Ceramic tile & Oyster shell & \\
\hline & & & & Coconut shell \\
\hline \multirow[t]{2}{*}{ ST1_NL } & Ceramic tile & PVC & & \\
\hline & & & Oyster shell & Coconut shell \\
\hline \multirow[t]{2}{*}{ ST2_NL } & Oyster shell & Ceramic tile & PVC & \\
\hline & & & & Coconut shell \\
\hline \multirow[t]{2}{*}{ ST3_NL } & Ceramic tile & Oyster shell & PVC & \\
\hline & & & & Coconut shell \\
\hline \multirow[t]{2}{*}{ ST1_BL } & Ceramic tile & Oyster shell & PVC & \\
\hline & & & & Coconut shell \\
\hline \multirow[t]{2}{*}{ ST2_BL } & Ceramic tile & PVC & & \\
\hline & & & Oyster shell & Coconut shell \\
\hline \multirow[t]{2}{*}{ ST3_BL } & Ceramic tile & & & \\
\hline & & PVC & Oyster shell & Coconut shell \\
\hline \multirow[t]{2}{*}{ ST1_WE } & Ceramic tile & PVC & Oyster shell & \\
\hline & & & & Coconut shell \\
\hline \multirow[t]{2}{*}{ ST2_WE } & Ceramic tile & PVC & Oyster shell & \\
\hline & & & & Coconut shell \\
\hline ST3_WE & Ceramic tile & PVC & Oyster shell & Coconut shell \\
\hline
\end{tabular}




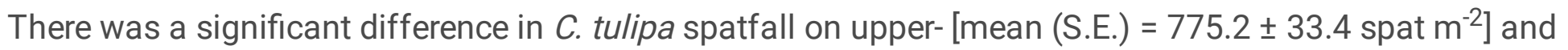
under-horizontal [mean $( \pm$ S.E. $)=2523.7 \pm 66.9$ spat m$^{-2}$ ] surfaces of collectors in the study conducted over 12 months (ANOVA $P<0.05$ ). Pooled mean and range of distribution of spatfall on upper-vs. underhorizontal surfaces of collectors were (mean \pm S.E.) $756.7 \pm 58.4(n=864 ; \mathrm{Q} 1=0.0$; Median = 0.0; Q3 = 670.7) and $3800 \pm 204(n=864 ; Q 1=0.0 ;$ Median = 1300.0; $Q 3=5283.0)$ spat $m^{-2}$ for Densu Delta, 2027 $\pm 106(n=1296 ; \mathrm{Q} 1=0.0 ;$ Median = 179.0; $\mathrm{Q} 3=2188.0)$ and $3920 \pm 155(\mathrm{n}=1296 ; \mathrm{Q} 1=136.0$; Median = 1448.0; $\mathrm{Q} 3=5874.0)$ spat $\mathrm{m}^{-2}$ for Narkwa Lagoon. Those for Benya Lagoon were $235.5 \pm 18.4(\mathrm{n}=1296$; $\mathrm{Q} 1=0.0 ;$ Median = 0.0; $\mathrm{Q} 3=188.7)$ and $2310 \pm 103(\mathrm{n}=1296 ; \mathrm{Q} 1=253.0 ;$ Median = 900.0; $\mathrm{Q3}=2600.0)$ spat $\mathrm{m}^{-2}$ whereas Whin Estuary had $75.09 \pm 9.37(\mathrm{n}=1296 ; \mathrm{Q} 1=0.0 ;$ Median $=0.0 ; \mathrm{Q} 3=0.0)$ and $489.8 \pm$ $40.9(n=1296 ; \mathrm{Q} 1=0.0 ;$ Median = 0.0; $\mathrm{Q} 3=236.7)$ spat $\mathrm{m}^{-2}$. Thus, wider variations in spatfall were observed on under-horizontal surfaces of collectors than on the upper side (see also interquartile range boxes in Figure 5). In each water body, there was further evidence of this phenomenon on a month-bymonth basis as indicated by the distribution of $C$. tulipa spatfall on the upper- and under-horizontal surfaces of the collectors deployed (Figure 5).

These profuse settlements on under-horizontal surfaces by $C$. tulipa spat on collectors, which were observed whilst collectors were placed in a "Face down" $/ 0^{\circ}$ orientation, were persistent in the experiments set up in March to test $C$. tulipa spat settlement on collectors oriented in the opposite "Face up" $/ 180^{\circ}$ direction. The interaction between orientation and collector surface was not significant (Table 3 ), thus, spatfall pattern on upper- and under- horizontal surfaces of collectors did not change with the change in orientation. Figure 6 shows details of higher spat settlement on the under-horizontal surface, recurring in both Densu Delta and Narkwa Lagoon in most instances for both orientations (T-test; $P_{\mathrm{t}}<0.05$ ).

Nonetheless, irrespective of the lesser observations of $C$. tulipa spatfall on upper-horizontal surfaces of Oyster shells compared to their undersides, there were no significant differences (T-test; $P_{\mathrm{t}}>0.05$ ) between the two sides in a $0^{\circ}$ orientation, in both water bodies (Figure 6). A typical example of $C$. tulipa spat settlement on upper- and under- horizontal surfaces of collectors deployed in this study is shown in Figure 7.

Table 3 - Results of three-way ANOVA for the effect of orientation on $C$. tulipa spatfall on collector surfaces (upper- and under-horizontal) of the different collector materials in the Densu Delta and Narkwa Lagoon, assessed in March 2018. 


\begin{tabular}{llllll}
\hline Source & DF & Adj SS & Adj MS & F-Value & P-Value \\
\hline Collector Surface (CS) & 1 & 37.361 & 37.3606 & 39.42 & 0.000 \\
\hline Collector material (CM) & 3 & 17.057 & 5.6858 & 6.00 & 0.001 \\
\hline Orientation (O) & 1 & 3.722 & 3.7219 & 3.93 & 0.049 \\
\hline $\mathrm{CS} \times \mathrm{CM}$ & 3 & 5.514 & 1.8381 & 1.94 & 0.123 \\
\hline $\mathrm{O} \times \mathrm{CM}$ & 3 & 6.616 & 2.2055 & 2.33 & 0.075 \\
\hline $\mathrm{CS} \times \mathrm{O}$ & 1 & 2.451 & 2.4507 & 2.59 & 0.109 \\
\hline $\mathrm{CS} \times \mathrm{O} \times \mathrm{CM}$ & 3 & 4.796 & 1.5986 & 1.69 & 0.170 \\
\hline Error & 272 & 257.780 & 0.9477 & & \\
\hline Total & 287 & 335.297 & & & \\
\hline
\end{tabular}

\section{Discussion}

Apart from the nylon mesh, which was eliminated after three months of not attracting spat, the other spat collectors proved to support the settlement of $C$. tulipa spat in natural ecosystems. The material structure, i.e. mesh size ( $2 \mathrm{~mm}$ diagonal) and thin nylon filaments of the mesh, coupled with instability in the water column may have contributed to unsuccessful $C$. tulipa spat settlement on the nylon mesh collector. Perhaps, a finer mesh-size material adapted to a more stable setup in the water column may produce positive results. Previous studies have demonstrated the use of wall tiles (Yankson, 1974), oyster shells (Yankson, 1974; Obodai, 1990) and coconut shells (Asare et al., 2019; Obodai, 1990), for collecting $C$. tulipa spat in lagoons and estuaries in Ghana. PVC was used to collect spat of other species of oysters; Crassostrea gigas in Wales (Laing and Earl, 1998), Crassostrea virginica in Georgia (Manley et al., 2008) and Pinctada maxima in Indonesia (Taylor et al., 1998a, 1998b, 1997). Ruwa and Polk (1994) successfully collected Crassostrea cucullata spat on coconut shells in Kenya.

In the present study, ceramic tile was the most effective $C$. tulipa spat collector, statistically similar to PVC but superior to both oyster shells (recycled) and coconut shells. Coconut shell collectors were the least attractive to spat in all the water bodies. The differences in efficiency among spat collectors used in this study could be due to the nature of their surfaces as Taylor et al. (1998a) identified surface contour to promote settlement of the pearl oyster Pinctada maxima. However, this phenomenon may not hold for $C$. tulipa in this study, as it would be expected that relatively contoured collectors, i.e. coconut and oyster shells, would have been most effective. Instead, the hard nature of materials such as ceramic tiles, PVC and oyster shells appeared to have provided a more stable substratum for the attachment of $C$. tulipa spat. On the other hand, the water absorption capacity of coconut shells (Rao et al., 2015) and the tendency to disintegrate in water may have rendered the relatively softer substrate, not as attractive as the other collectors for cementing by the pediveliger of $C$. tulipa during settlement. 
A comparative advantage of ceramic tiles could be their weight (each ceramic tile weighed $200 \mathrm{~g}$; the other collectors weighed $<50 \mathrm{~g}$ each), probably making it relatively less perturbed by water currents and providing more stability for settlement of $C$. tulipa spat. However, it is extremely difficult to detach whole/live spat from ceramic tiles and oyster shells as experienced during monthly cleaning of collectors prior to re-deployment. In addition, tile collectors are brittle and break easily when they fall. This may increase losses and affect production cost if used in commercial spat collection. The utilisation of ceramic tiles as collectors on a $C$. tulipa farm will therefore require intensive labour for cleaning collectors and great care to prevent losses. In contrast, coconut shells require moderate effort whilst PVC requires minimal time and effort to detach almost all spat undamaged, corroborating the 95-100\% spat removal success reported by Wedler (1980) for PVC. This is probably the reason PVC is the most widely used in recent times for oyster culture (Gosling, 2015).

Further, preparation and construction of ceramic tiles and PVC collectors require skilled labour whilst coconut and oyster shells can be prepared by the culturist with little skill. The culturist, therefore, will have to decide on the type of collector based on availability, expertise and purpose. $C$. tulipa spat to be collected and detached for onward culturing in different grow-out facilities may be best done using PVC slats. Those meant for rearing on collectors would be ideal on ceramic tiles and oyster shells. The biodegradable coconut shells would be ideal for bottom culture (Quayle and Newkirk, 1989) and useful in oyster restoration programmes. In addition, growth and survival of spat may be critical in the choice of collectors by culturists beyond settlement.

Experimental racks in this study were fitted with vertical series of horizontally strung collectors. This was guided by conclusions on horizontally placed collectors yielding the greatest number of spat in other species of oysters by several studies in the past (Hopkins, 1937; Schaefer, 1937; Cole and Knight-Jones, 1939; Taylor et al., 1998a). However, reported observations by these authors on spat settlement on upper and under surfaces of horizontally placed collectors are inconclusive. In furthering information on the orientation effect of oyster spat collectors, the present study demonstrated the abundance of $C$. tulipa spat on under-horizontal surfaces of all the types of collectors in every month in each of the coastal water bodies, similar to the findings of Hopkins (1937) and Schaefer (1937) for Ostrea Iurida and C. gigas spat respectively.

Earlier work by Cole and Knight-Jones (1939) however, showed a marked tendency for the larvae of Ostrea edulis to attach in daylight. In contrast, Shaw, Arnold and Stallworthy (1970) concluded that setting activity in mature larvae of $C$. virginica was encouraged by darkness and partially inhibited by light. Ajana (1979) also recorded best concentration of $C$. gasar (=tulipa) spat on shaded collectors. The observation of profuse settlement of $C$. tulipa spat on under-horizontal surfaces of artificial collectors in the present study demonstrates a possible escape from light or simply a quest for shaded areas (i.e. negative phototaxis) by the pediveliger. It could be assumed that undersides of the collectors used in this study received relatively lesser illumination and therefore attracted more spat than the upper surfaces. 
The significantly larger sizes of $C$. tulipa spat settled on under-horizontal surfaces, mean (S.E.) $9.88 \pm 0.5$ $\mathrm{mm}$, as opposed to the converse, $5.99 \pm 0.5 \mathrm{~mm}$, of the same collector (Figure 7), is most probably due earlier attachment. Thus, the descriptions of the morphological and anatomical structure of the larvae of C. virginica (Galtsoff, 1964) and O. edulis (Cole and Knight-Jones, 1939; Cranfield, 1974) would suggest that larval movement prior to setting could most likely account for the observation for $C$. tulipa in this study. The free-swimming veliger possesses a foot, for attachment, near the velum (which is an outgrowth of the prototroch of the previous trochophore larva) with cilia for swimming forward and upward with foot and velum uppermost (Galtsoff, 1964). Since larval formation is identical for Ostrea and Crassostrea (Galtsoff, 1964), the $C$. tulipa larvae, like other oyster larvae, swimming upside down with the foot uppermost, presents the best chance of attaching to undersides of horizontally suspended substrates even under turbulent natural conditions; upward swimming of competent larvae of $C$. virginica was found to persist in highly turbulent flow by Wheeler et al. (2013). In addition, Baker (1997) provides evidence of geotaxis, i.e. movement influenced by gravity, as a stronger settlement cue than phototaxis and rugotaxis for $C$. virginica, stating pediveligers of both Crassostrea and Ostrea possess statocysts, which are thought to be geosensory.

\section{Conclusion}

The $2 \mathrm{~mm}$ nylon mesh did not harvest any $C$. tulipa spat after three months of deployment in the coastal water bodies studied. On the other hand, coconut shell, oyster shell, PVC, and ceramic tiles demonstrated the capacity to harvest $C$. tulipa spat from the wild. Ceramic tile was the most effective $C$. tulipa spat collector among the four, although PVC material could be equally effective. $C$. tulipa farmers should consider other factors including cost of collector material, its amenability to culture technique and holding facilities, availability, and durability in making a suitable choice between ceramic tile and PVC. These collectors should be deployed suspended horizontally in the water column with their undersides exposed for maximum attachment of $C$. tulipa spat.

\section{Declarations}

\section{Declaration of Competing Interest}

We declare that we do not have any known financial interest or personal relationships that could be deemed a conflict of interest in relation with this work.

\section{Acknowledgements}

Funding: This work was supported by the United States Agency for International Development (USAID) and the University of Cape Coast Fisheries and Coastal Management Capacity Building Support Project (641-A18-FY14-IL\#007)

We are grateful to Dr. Noble Asare - Head of the Department of Fisheries and Aquatic Sciences, University of Cape Coast, Prof. Denis Worlanyo Aheto - Director of the World Bank Africa Centre of 
Excellence in Coastal Resilience (ACECoR), and Ms. Esinam Attipoe - Project Management and Technical Support Person of the USAID/UCC Fisheries and Coastal Management Capacity Building Support Project, for their approval and coordination in providing additional logistics for the field work.

\section{References}

Adite, A., Abou, Y., Sossoukpê, E., Fiogbé, E.D., 2013. The oyster farming in the coastal ecosystem of southern Benin (West Africa): environment, growth and contribution to sustainable coastal fisheries management. Int. J. Dev. Res. 3, 087-094.

Ahmed, N., 2007. Economics of aquaculture feeding practices: Bangladesh, in: Hasan, M.R. (Ed.), Economics of Aquaculture Feeding Practices in Selected Asian Countries. FAO Fisheries Technical Paper, Rome, FAO, pp. 33-64.

Ajana, A.M., 1980. Fishery of the mangrove oyster, Crassostrea gasar, Adanson (1757), in the Lagos area, Nigeria. Aquaculture 21, 129-137. https://doi.org/10.1016/0044-8486(80)90021-6

Ajana, A.M., 1979. Preliminary investigation into some factors affecting the settlement of the larvae of the mangrove oyster Crassostrea gasar (Adanson) in the Lagos lagoon, in: Proceedings of the 6th European Malacology Congress. pp. 271-275.

Asare, B., Obodai, E.A., Acheampong, E., 2019. Mangrove oyster farming: Prospects as supplementary livelihood for a Ghanaian fishing community. J. Fish. Coast. Manag. 1, 7-14.

https://doi.org/10.5455/jfcom.20190311090846

Baker, P., 1997. Settlement site selection by oyster larvae, Crassostrea virginica: Evidence for geotaxis. J. Shellfish Res. 16, 125-128.

Chuku, E.O., Osei, I.K., 2017. Minimizing losses in cultch construction materials towards a profitable oyster (Crassostrea tulipa) farming business in Coastal Ghana, in: Book of Abstracts: Conference on Fisheries and Coastal Environment. University of Cape Coast, Accra, p. 78.

Cole, H.A., Knight-Jones, E.W., 1939. Some Observations and Experiments on the Setting Behaviour of Larvae of Ostrea edulis. ICES J. Mar. Sci. 14, 86-105.

https://doi.org/https://doi.org/10.1093/icesjms/14.1.86

Cormier-Salem, M.C., Bernatets, C., Sarr, O., 2010. Mangrove System Sustainability: Public Incentives and Local Strategies in West Africa, in: Hoanh, C.T., Szuster, B.W., Suan-Pheng, K., Ismail, A.M., Noble, A.D. (Eds.), Tropical Deltas and Coastal Zones: Food Production, Communities and Environment at the LandWater Interface. International Water Management Institute (IWMI), Oxfordshire, pp. 409-421. https://doi.org/10.1079/9781845936181.0133 
Cranfield, H.J., 1974. Observations on the morphology of the mantle folds of the pediveliger of Ostrea edulis L. and their function during settlement. J. Mar. Biol. Assoc. United Kingdom 54, 1-12. https://doi.org/10.1017/s0025315400022062

Dégremont, L., Ernande, B., Bédier, E., Boudry, P., 2007. Summer mortality of hatchery-produced Pacific oyster spat (Crassostrea gigas). I. Estimation of genetic parameters for survival and growth. Aquaculture 262, 41-53. https://doi.org/10.1016/j.aquaculture.2006.10.025

FAO, 2014. The State of World Fisheries and Aquaculture 2014 - Opportunities and challenges. FAO, Rome.

Friedman, K.J., Bell, J.D., Tiroba, G., 1998. Availability of wild spat of the blacklip pearl oyster, Pinctada margaritifera, from "open" reef systems in Solomon Islands. Aquaculture 167, 283-299. https://doi.org/10.1016/S0044-8486(98)00286-5

Galtsoff, P.S., 1964. The American Oyster Crassostrea virginica Gamelin: Larval development and metamorphosis, in: Fishery Bulletin of the Fish and Wildlife Service. U.S. Government Printing Office, Washington DC, pp. 355-380.

Giese, A.C., Pearse, J.S., 1979. Reproduction of Marine Invertebrates. Acad. Press 5, 374. https://doi.org/10.1006/jfbi.2002.2077

Gosling, E., 2015. Marine Bivalve Molluscs, 2nd ed. John Wiley \& Sons, Ltd, Chichester, West Sussex. https://doi.org/10.1002/9781119045212

Helm, M.M., Bourne, N., 2004. Hatchery culture of bivalves. A practical manual, No. 471. ed. FAO Fisheries Technical Paper, Rome, FAO.

Hopkins, A.E., 1937. Experimental observations on spawining, larval development, and setting in the Olympia oyster Ostrea Iurida. Bull. U.S. Bur. Fish. 48, 439-503.

Hsu, J.C., 1992. Stepwise multiple comparisons with the best. J. Stat. Plan. Inference 33, 197-204. https://doi.org/10.1016/0378-3758(92)90067-3

Ishengoma, E.B., Jiddawi, N.S., Tamatamah, R.A., Mmochi, A.J., 2011. Wild Black-lip Pearl Oyster (Pinctada margaritifera) spat collection in Tanzania. West. Indian Ocean J. Mar. Sci. 10, 49-57.

Janha, F., Ashcroft, M., Mensah, J., 2017. Participatory Rural Appraisal (PRA) Densu Estuary Oyster Harvesting, Bortianor/Tsokomey, Ga-South Municipal Assembly, Greater Accra Region, Ghana. Accra.

Kamara, A.B., 1982. Preliminary studies to culture Mangrove Oysters, Crassostrea tulipa, in Sierra Leone. Aquacultue 27, 285-294. 
Laing, I., Earl, N.H., 1998. The lipid content, spatfall and subsequent growth of early and late settling hatchery-reared pacific oyster, Crassostrea gigas Thunberg, larvae. Aquac. Res. 29, 19-25.

https://doi.org/10.1046/j.1365-2109.1998.00931.x

Manley, J., Power, A., Walker, R., 2008. Wild Eastern oyster, Crassostrea virginica, spat collection for commercial grow-out in Georgia. University of Georgia Marine Extension Service, Georgia.

Mann, R., 1983. Bivalve mollusc hatcheries: A critical appraisal of their development and a review of their potential value in enhancing the fisheries of developing nations. Mems Asoc. Latinoam. Acuicult. 5, 97105.

Miller, W.W., Hall, C., 1995. Aquaculture curriculum guide. Agric. Educ.

Nayar, K.N., Rajapandian, M.E., Gandhi, A.D., Gopinathan, C.P., 1980. Larval rearing and production of spat of the oyster Crassostrea madrasensis (Preston) in an experimental hatchery 14.

Obodai, E.A., 1990. Aspects of ecology and biology of the West African Mangrove Oyster, Lamarck, occurring in some coastal waters of Ghana, West Africa. University of Cape Coast.

Obodai, E.A., Yankson, K., 2002. The relative potential of three tidal lagoons in Ghana for oyster (Crassostrea tulipa) culture. J. Nat. Sci. 2, 1-16.

Obodai, E.A., Yankson, K., Blay, J.J., 1991. Seasonal Changes in Hydrographic Factors and Breeding in Two Populations of Crassostrea tulipa (Lamarck). Ghana J. Sci. 31, 45-51.

Pillay, T.V.R., Kutty, M.N., 2005. Aquaculture: Principles and practices, 2nd Ed. ed. Blackwell Publishing, Oxford.

Quayle, D.B., Newkirk, G.F., 1989. Farming bivalve molluscs: methods for study and development. The World Aquaculture Society, Baton Rouge, LA.

Rao, K.V., Swaroop, A.H.L., Rao, K.R., Bharath, N., 2015. Study on Strength Properties of Coconut Shell Concrete. Int. J. Civ. Eng. Technol. 6, 42-61.

Ruwa, R.K., Polk, P., 1994. Patterns of spat settlement recorded for the tropical oyster Crassostrea cucullata (Born 1778) and the barnacle, Balanus amphitrite (darwin 1854) in a mangrove creek. Trop. Zool. 7, 121-130. https://doi.org/10.1080/03946975.1994.10539246

Schaefer, M.B., 1937. Attachment of the Larvae of Ostrea gigas, the Japanese Oyster, to Plane Surfaces. Ecology 18, 523-527. https://doi.org/10.2307/1930578

Shaw, R., Arnold, D.C., Stallworthy, W.B., 1970. Effects of Light on Spat Settlernent of the Arnerican Oyster (Crossostrea virginica). J. Fish. Res. Board Canada 27, 743-748. 
Soria, G., Lavín, M.F., Cudney-Bueno, R., 2015. Spat availability of commercial bivalve species recruited on artificial collectors from the northern Gulf of California. Seasonal changes in species composition. Aquac. Res. 46, 2829-2840. https://doi.org/10.1111/are.12435

Southgate, P.C., Lucas, J.S., 2008. The pearl oyster. Elsevier, Oxford.

Tanyaros, S., Chuseingjaw, S., 2016. A partial substitution of microalgae with single cell detritus produced from seaweed (Porphyra haitanensis) for the nursery culture of tropical oyster (Crassostrea belcheri). Aquac. Res. 47, 2080-2088. https://doi.org/10.1111/are.12662

Taylor, J.J., Rose, R.A., Southgate, P.C., 1997. Inducing detachment of silver-lip pearl oyster (Pinctada maxima, Jameson) spat from collectors. Aquaculture 159, 11-17. https://doi.org/10.1016/S00448486(97)00201-9

Taylor, J.J., Southgate, P.C., Rose, R.A., 1998a. Assessment of artificial substrates for collection of hatchery-reared silver-lip pearl oyster (Pinctada maxima, Jameson) spat. Aquaculture 162, 219-230.

Taylor, J.J., Southgate, P.C., Rose, R.A., 1998b. Effects of mesh covers on the growth and survival of silverlip pearl oyster (Pinctada maxima, Jameson) spat. Aquacultue 162, 241-246.

Theisen, D., 2010. Pilot Ba Nafaa Oyster Culture Project. Tanbi, The Gambia.

Urban, H.J., 2000. Culture potential of the pearl oyster (Pinctada imbricata) from the Caribbean. I. Gametogenic activity, growth, mortality and production of a natural population. Aquaculture 189, 361373. https://doi.org/10.1016/S0044-8486(00)00393-8

Vakily, J.M., 1989. The biology and culture of mussels of the genus Perna, ICLARM Studies and Reviews.

Wedler, E., 1980. Experimental spat collecting and growing of the oyster, Crassostrea rhizophorae guilding, in the Ciénaga Grande de Santa Marta, Colombia. Aquaculture 21, 251-259. https://doi.org/10.1016/0044-8486(80)90135-0

Wheeler, J.D., Helfrich, K.R., Anderson, E.J., McGann, B., Staats, P., Wargula, A.E., Wilt, K., Mullineaux, L.S., 2013. Upward swimming of competent oyster larvae Crassostrea virginica persists in highly turbulent flow as detected by PIV flow subtraction. Mar. Ecol. Prog. Ser. 488, 171-185. https://doi.org/10.3354/meps10382

Yankson, K., 2004. Fish from the shell: Its potential in the quest for adequate protein in Ghana, Inaugral Lecture. Cape Coast.

Yankson, K., 1990. Preliminary Studies on the Rearing of the West African Mangrove Oyster Crassostrea tulipa in the Laboratory. Discov. Innov. 2, 45-51. 
Yankson, S.C.K., 1974. Preliminary study of some aspects of the biology of the Mangrove Oyster (Ostrea tulipa) in the Elmina Lagoon. University of Cape Coast.

\section{Figures}
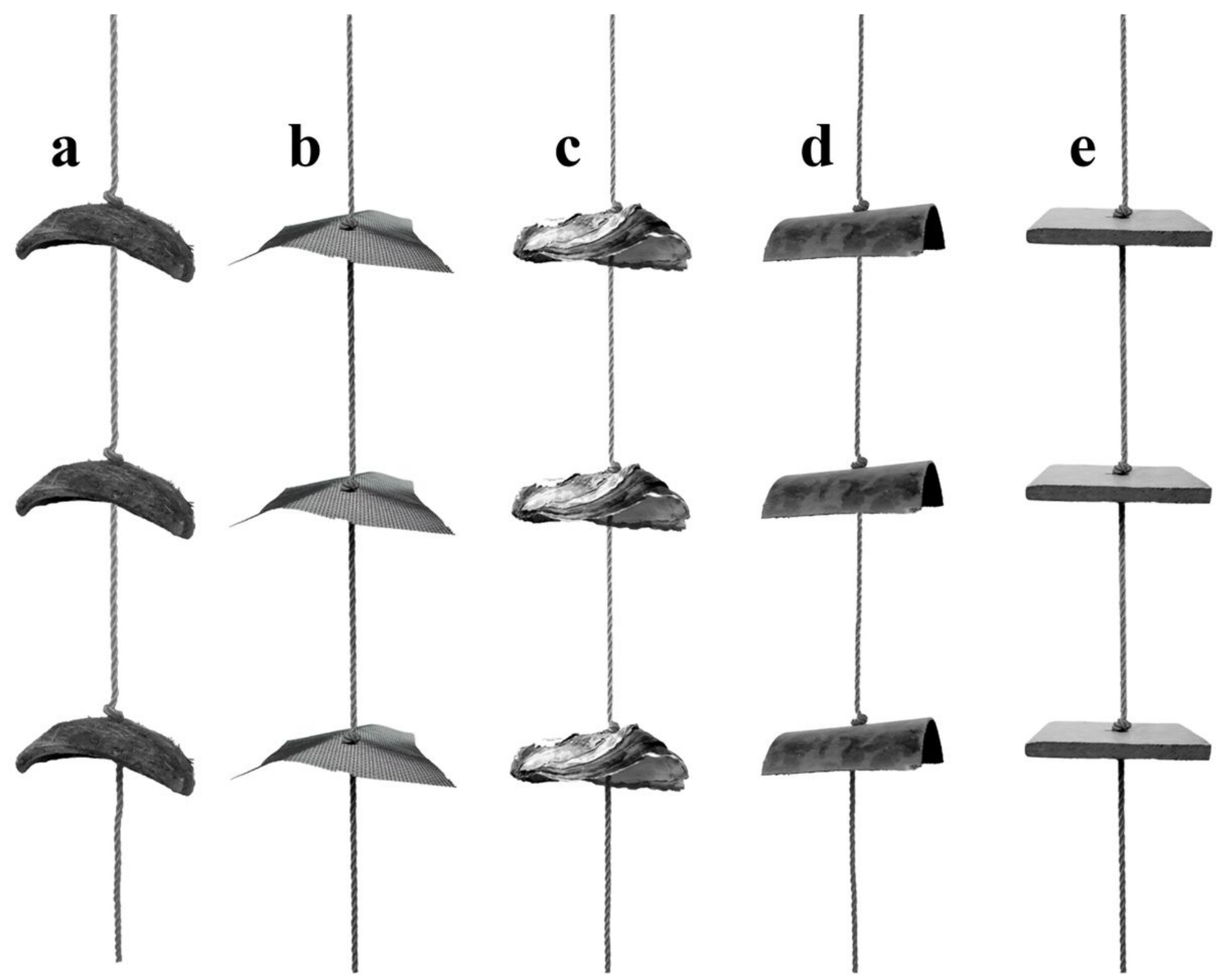

Figure 1

Collectors used for the study; (a) coconut shell, (b) nylon mesh, (c) oyster shell, (d) PVC slats and (e) ceramic tiles. 

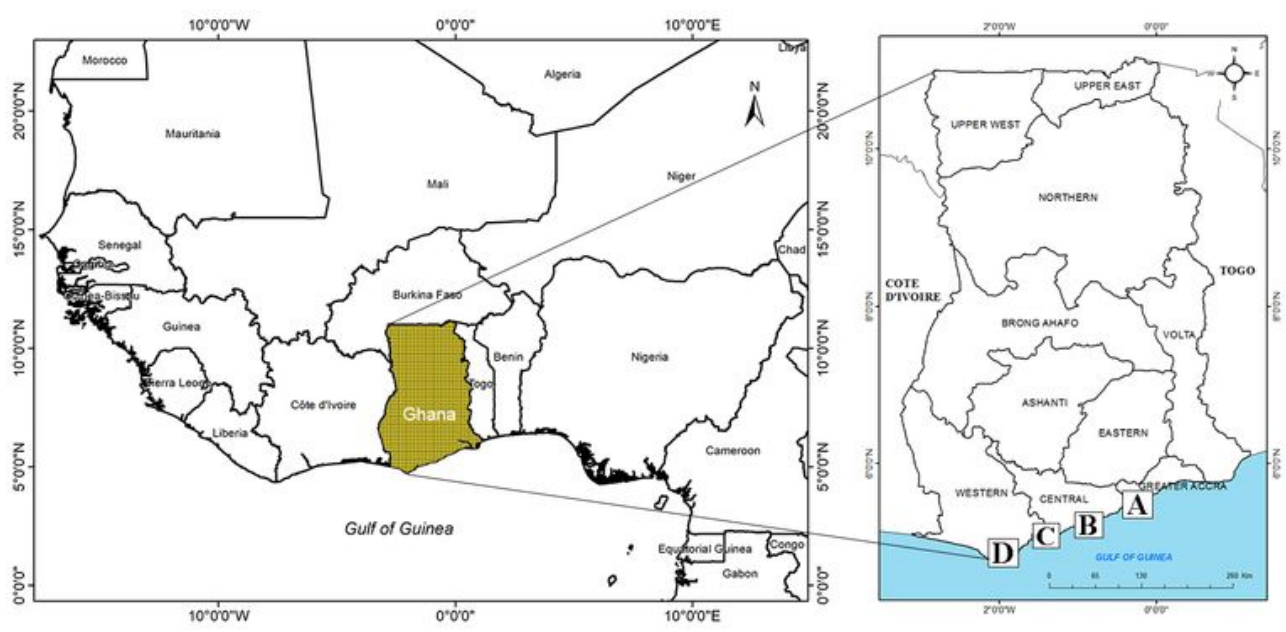

\section{LEGEND}

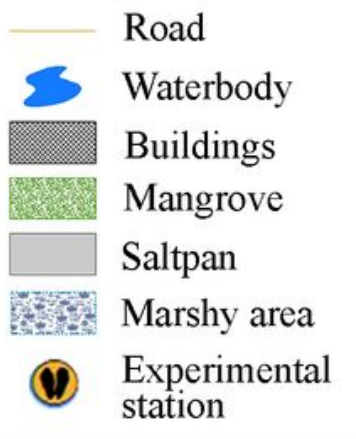
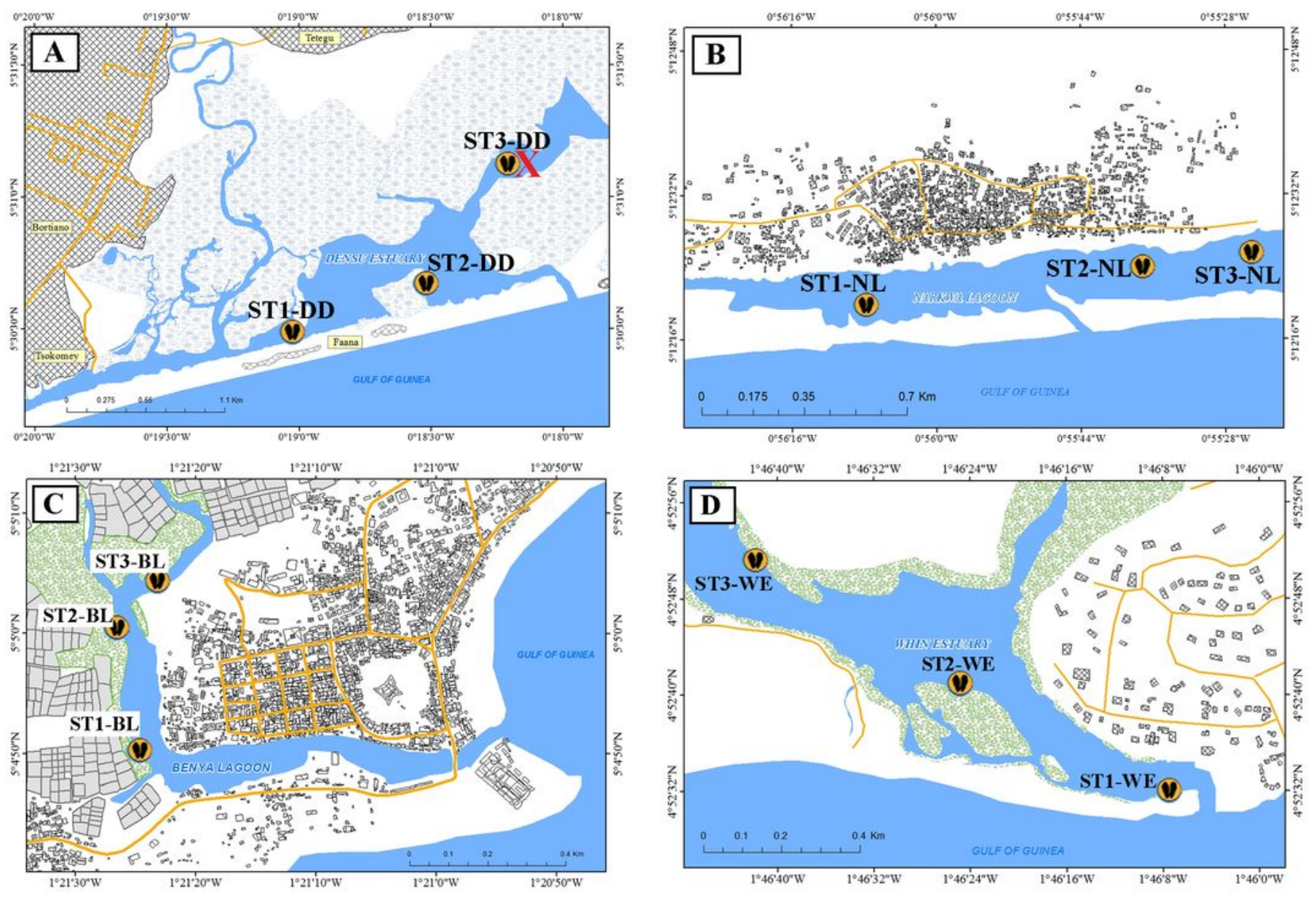

\section{Figure 2}

Maps of study areas showing experimental stations (ST) in the (A) Densu Delta - DD, (B) Narkwa Lagoon - NL, (C) Benya Lagoon - BL, and (D) Whin Estuary - WE. (X = station eliminated due to recurrent destruction of rack) 


\section{Face down $\left(0^{\circ}\right)$}
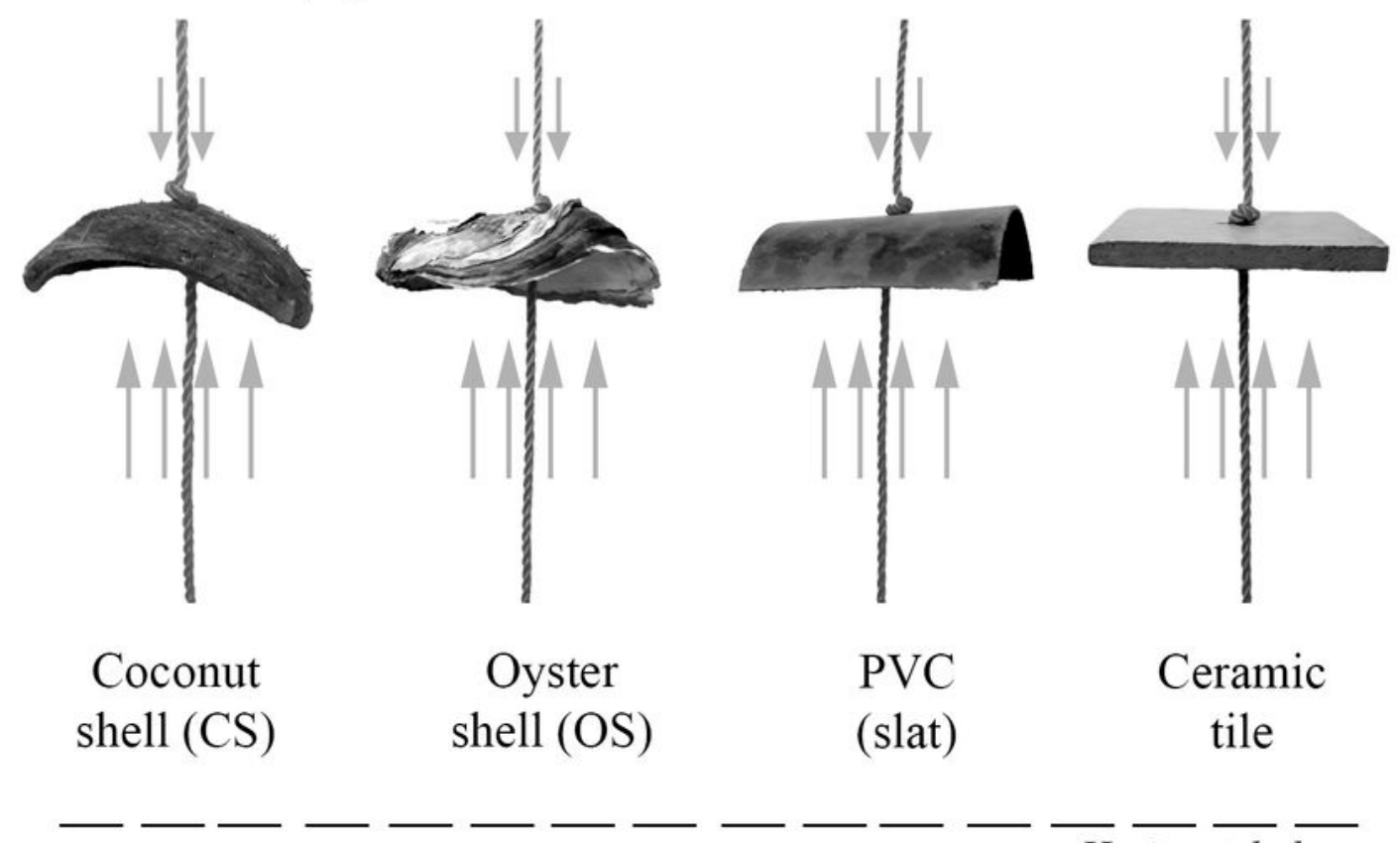

PVC

(slat)
Ceramic

tile

\section{Face up $\left(180^{\circ}\right)$}
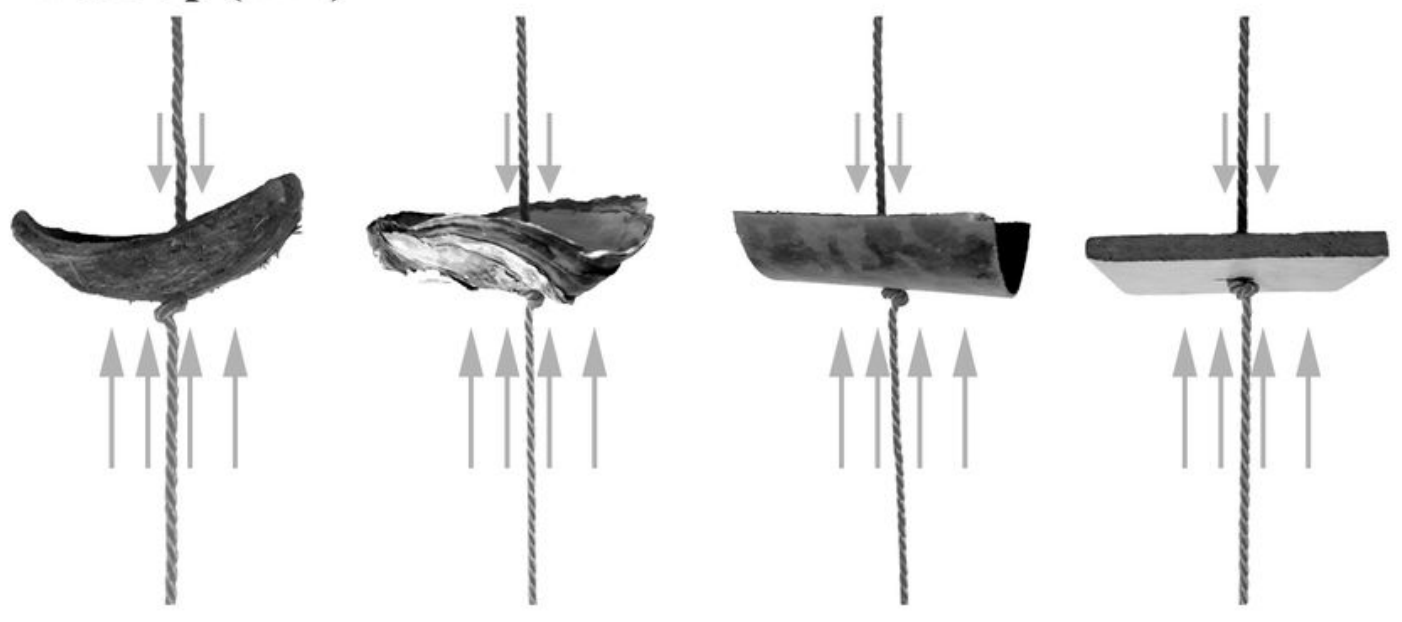

\section{$\uparrow \uparrow \uparrow \uparrow \quad$ Under-horizontal surface \\ $\downarrow \downarrow$ Upper-horizontal surface}

\section{Figure 3}

An illustration of the different collectors/substrates depicting the "face down" $\left(0^{\circ}\right)$ and "face up" $\left(180^{\circ}\right)$ orientations and collector surfaces in the horizontal position 

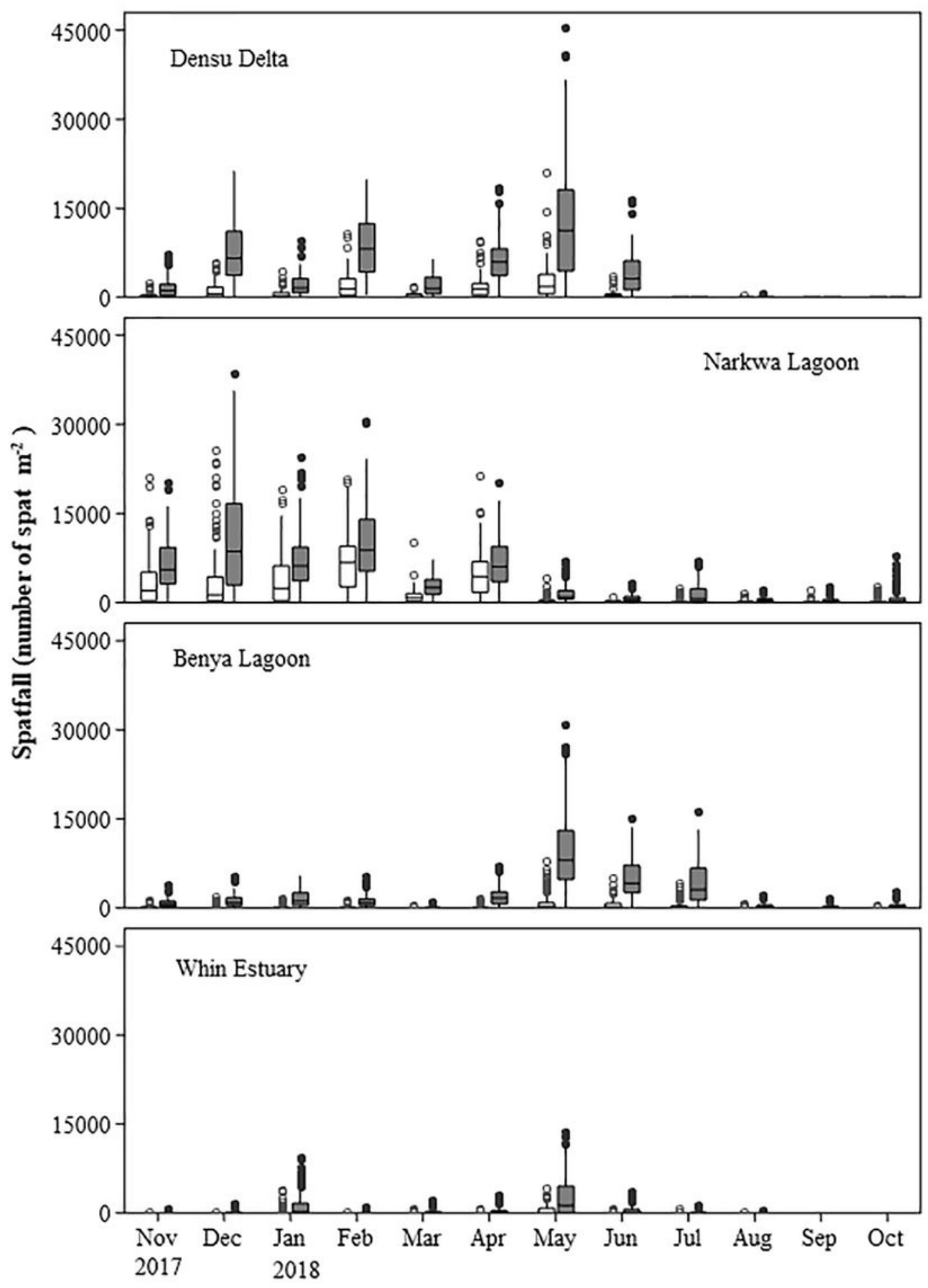

Figure 4

Crassostrea tulipa spatfall (mean \pm S.E.) on the collectors deployed in the selected coastal water bodies from November 2017 to October 2018. Means are pooled for the four water bodies. 


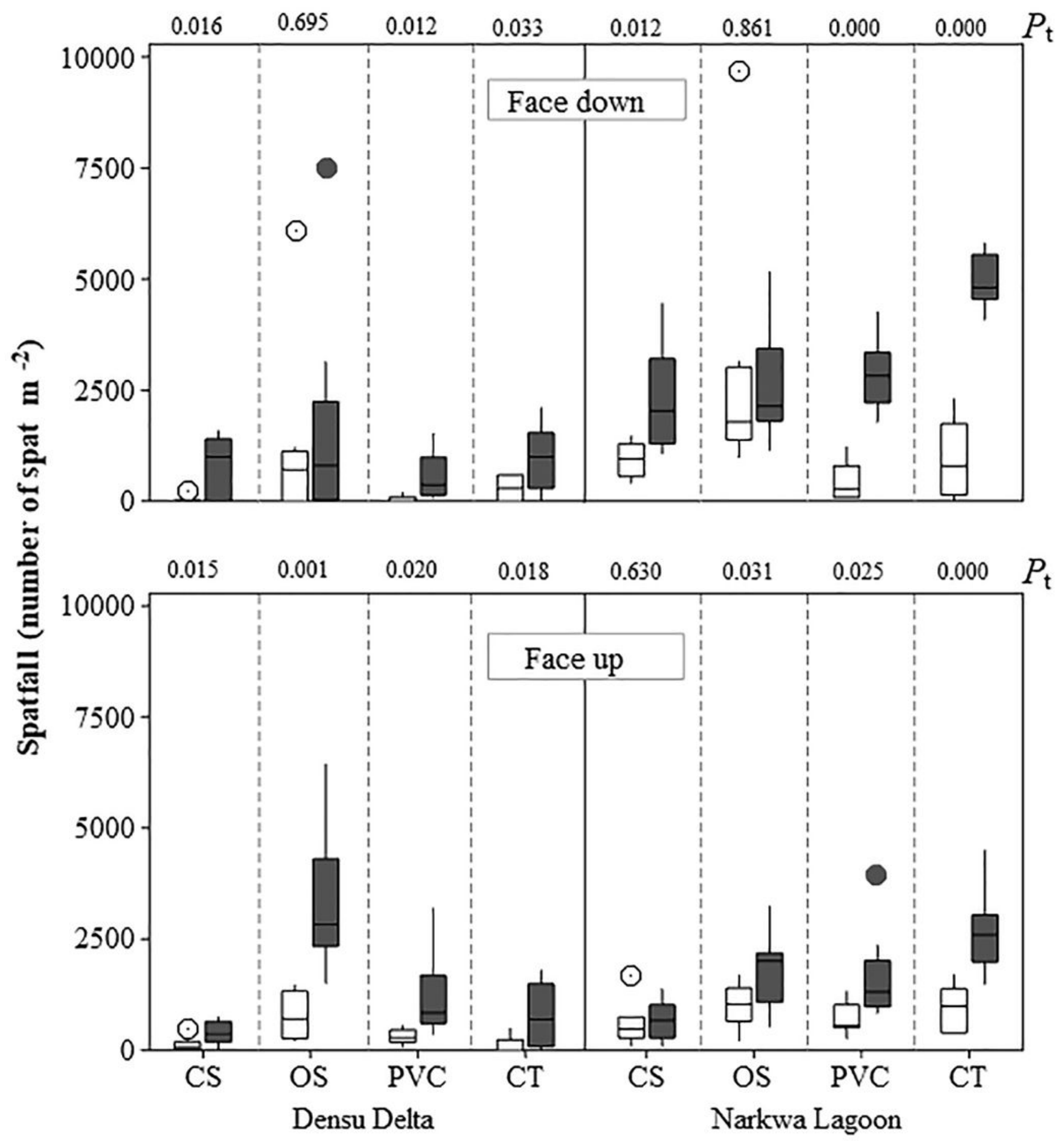

Figure 5

Statistical analysis of the effect of two positional orientations ("Face down" and "Face up") on C. tulipa spat settlement on upper- and under- horizontal surfaces of the artificial collectors (CS = Coconut shell; OS = Oyster shell; $\mathrm{CT}=$ Ceramic tile). Pt value is the statistical result for the t-test of the null hypothesis $\mathrm{H} \rrbracket: \mu \rrbracket-\mu \rrbracket=0$ between upper- and under-horizontal surfaces of collectors. 

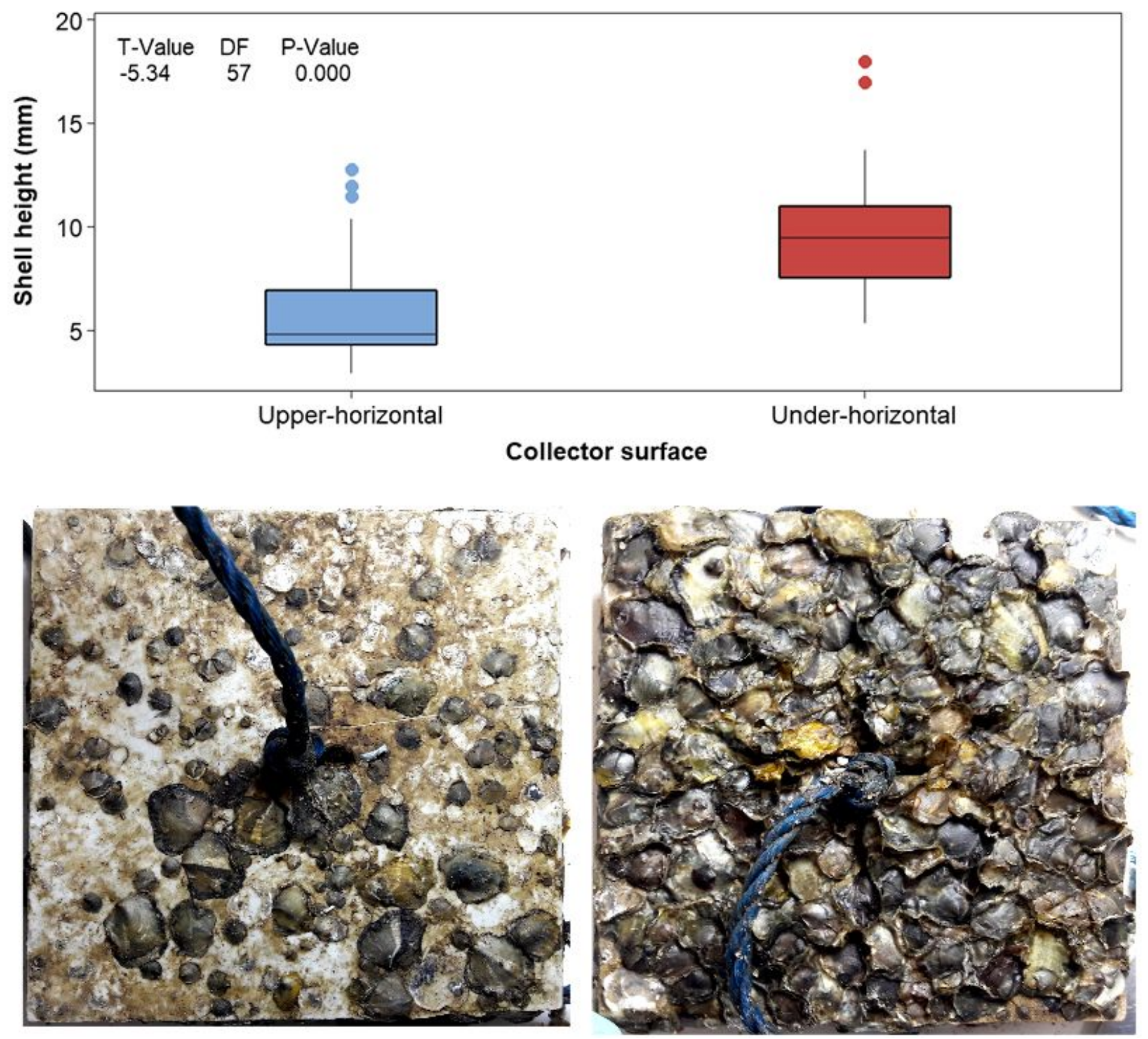

Figure 6

Typical occurrence of larger sizes and greater settlement of Crassostrea tulipa spat on the underhorizontal surface (right) than the upper-horizontal surface (left) of the same collector (In this illustration, $10 \times 10 \mathrm{~cm} 2$ ceramic tile). 